\title{
Effects of the Bioregulators
}

Aminoethoxyvinylglycine and Ethephon on Brix, Carbohydrate, Acid, and Mineral Concentrations in 'Scarletspur Delicious' Apple Juice

\author{
S.R. Drake ${ }^{1}$ \\ U.S. Department of Agriculture, Agricultural Research Service, Tree Fruit \\ Research Laboratory, 1104 North Western Avenue, Wenatchee, WA 98801
}

T.A. Eisele ${ }^{2}$

Tree Top, Inc., P.O. Box 248, Selah, WA 98942

D.C. Elfving ${ }^{3}$

Washington State University, Tree Fruit Research and Extension Center, 1100 North Western Avenue, Wenatchee, WA 98801

M.A. Drake ${ }^{4}$ and S.L. Drake 4 Department of Food Science, North Carolina State University, Raleigh, NC 27695

D.B. Visser ${ }^{6}$

Washington State University, Tree Fruit Research and Extension Center, 1100 North Western Avenue, Wenatchee, WA 98801

\begin{abstract}
In a study conducted over three crop seasons, Ethrel (ETH) increased the Brix, sucrose, and sorbitol content of 'Scarletspur Delicious' apple juice while reducing the fructose content. Both longer preharvest exposure to, and higher concentrations of, ETH had a stronger influence than application closer to harvest and/or at lesser amounts. Time of ETH application tended to influence individual carbohydrates more so than amount of ETH applied. ETH reduced total acidity and also reduced apple juice individual acid (quinic and malic) contents with longer preharvest exposure or higher concentrations. Aminoethoxyvinylglycine [AVG (ReTain)] reduced both Brix and sucrose content of 'Scarletspur Delicious' apple juice, but had no influence on either total acidity or individual acid contents. Combinations of AVG with ETH tended to counteract the influence of either used alone on total Brix, carbohydrates, total acidity and individual acids. Mineral content of 'Scarletspur Delicious' apple juice was not strongly influenced by application of either ETH or AVG.
\end{abstract}

Bioregulators have been used for multiple purposes in tree fruit production and many physiological processes in tree fruit can be influenced by exogenous application of such products. Aminoethoxyvinylglycine $[\mathrm{AVG}$ (ReTain), Valent BioSciences, Walnut Creek, Calif.] and ethephon [ETH (Ethrel) Bayer CropScience, Research Triangle Park, N.C.] have been widely used alone or in combination to manipulate fruit tree physiology. Control of vegetative growth and regulation of flowering (Elfving and Cline, 1990; Elfving et al., 2003; Halder-Doll and Bangerth, 1987), preharvest drop (Bangerth, 1978; Greene et al., 2000; Greene, 2002), fruit maturity (Byers, 1997;

\footnotetext{
Received for publication 26 Jan. 2005. Accepted for publication 3 mar. 2005. The authors wish to express appreciation to the Washington State Tree Fruit Research Commission for grant funds partially supporting this study.

${ }^{1}$ Research horticulturist.

${ }^{2}$ Senior chemist.

${ }^{3}$ Professor and horticulturist.

${ }^{4}$ Associate food scientist.

${ }^{5}$ Research associate.

${ }^{6}$ Agricultural technician II.
}

Layne et al., 2002; Stover et al., 2003 ), fruit size, shape, color, firmness and postharvest quality (Andrews, 2001; Beaudry and Jayanty, 2003; Drake et al., 2002a, 2003; Larrigaudiere, 1996; Wang and Dilley, 2001; Watkins and Rosenberger, 1999; Williams, 1980) have been manipulated with the use of bioregulators. There is little, if any, information on the compositional characterization of apple juice from apples treated with bioregulators, even though there has been extensive characterization of apple juice from non-treated cultivars (Drake and Eisele, 1999; Eisele and Drake, 2003; Elkins et al., 1996; Lee and Wrolstad, 1988). Therefore, the objective of this study was to determine the influence of the bioregulators AVG and ETH on the Brix, titratable acidity, carbohydrate, acid and mineral concentrations in apple juice using the 'Scarletspur Delicious' apple strain, widely grown in Washington today.

\section{Materials and Methods}

This study was conducted over three crop seasons using mature 'Scarletspur Delicious' apple trees (Malus domestica Borkh.) on
MM.111 rootstock. Trees were located in a commercial orchard in East Wenatchee, Wash., and were planted in 1979 at a spacing of $3.3 \times 6.6 \mathrm{~m}$.

Trial 1 (2000). Applications of ETH were made to single-tree plots in six randomized complete blocks to run-off using a hydraulic hand-gun sprayer. Apple trees were sprayed at either 1 or 2 weeks before first (commercial) harvest (1 WBFH, $2 \mathrm{WBFH}$ ) with either 150 or $300 \mathrm{mg}$ active ingredient (a.i.)/L ETH. All sprays were supplemented with $0.1 \% \mathrm{v} / \mathrm{v}$ Regulaid surfactant (Kalo, Overland Park, Kan.). Control trees were unsprayed.

Trial 2 (2001). Five randomized complete blocks containing six double-tree plots each were selected from another part of the orchard that had not been previously treated with either AVG or ETH. Five double-tree plots per block (10 trees per block) were sprayed $4 \mathrm{WBFH}$ with $125 \mathrm{mg}$ a.i./L AVG plus $0.1 \% \mathrm{v} / \mathrm{v}$ Sylgard 309 organosilicone surfactant (Wilbur-Ellis, Fresno, Calif.) to runoff using a hydraulic hand-gun sprayer. The sixth double-tree plot in each block served as an unsprayed control. The other four double-tree plots previously treated with AVG were individually sprayed to runoff using a hydraulic handgun sprayer with the following combinations of ETH and timing: ETH $150 \mathrm{mg}$ a.i./L at either $2 \mathrm{WBFH}$ or $1 \mathrm{WBFH}$ or ETH $300 \mathrm{mg}$ a.i./L at either $2 \mathrm{WBFH}$ or 1 WBFH. All ETH sprays were supplemented with $0.1 \% \mathrm{v} / \mathrm{v}$ Regulaid surfactant.

Trial 3 (2002). Seven randomized complete blocks containing six four-tree plots each were selected from another part of the orchard that had not been previously treated with either AVG or ETH. Three four-tree plots per block (12 trees per block) were sprayed $4 \mathrm{WBFH}$ with $125 \mathrm{mg}$ a.i./L AVG plus $0.1 \% \mathrm{v} / \mathrm{v}$ Sylgard 309 organosilicone surfactant to runoffusing a hydraulic hand-gun sprayer. One four-tree plot in each block served as an unsprayed control. The other two four-tree plots previously treated with AVG were individually sprayed with either ETH $150 \mathrm{mg}$ a.i./L at $2 \mathrm{WBFH}$ or with ETH $75 \mathrm{mg}$ a.i./L at $2 \mathrm{WBFH}$ and again at 1 WBFH to run-off using a hydraulic hand-gun sprayer. The remaining two untreated four-tree plots were treated with ETH at either 75 or 150 mg a.i./L as described above. All ETH sprays were supplemented with $0.1 \% \mathrm{v} / \mathrm{v}$ Regulaid surfactant.

'Scarletspur Delicious' apples were harvested on two dates each year of the study corresponding to first commercial harvest and commercial harvest +4 weeks (18 Sept. and 13 Oct., 2000; 10 Sept. and 8 Oct., 2001; 23 Sept. and 21 Oct., 2002). On each harvest date, thirty apples were harvested at random from each plot. After each harvest, the apples were held in refrigerated storage (1 week) before analysis.

Juice preparation. Each group of ten apples (treatment, harvest and replication) was washed, surface dried, sliced and juiced using a juicer (model 4000; Omega Products, Inc., Harrisburg, Pa.) at ambient temperatureSubsequent juice was centrifuged in an IEC (Centra-7; International Eq. Co., Needham Heights, Mass.) at $5000 \mathrm{rpm}$ and then filtered 
through an odor free coffee filter to remove all insoluble solids. About $150 \mathrm{~mL}$ of juice from each group were placed in a plastic bottle and frozen until sufficient samples had been collected for analysis.

Previously frozen samples were thawed overnight at $2{ }^{\circ} \mathrm{C}$. Titratable acidity (AOAC 942.15) and degrees Brix values (AOAC 932.12) (AOAC, 1990) were measured on all samples prior to HPLC analysis. Carbohydrate and acid concentrations were determined as previously described (Drake and Eisele, 1999). Sodium, potassium, magnesium and calcium concentrations were determined by atomic absorption spectrophotometry using a modified AOAC 985.35 procedure. Ten $\mathrm{ml}$ aliquots of each juice sample were diluted to a final volume of $100 \mathrm{~mL}$ with $1 \mathrm{~N}^{\mathrm{HNO}}$ containing $0.1 \%$ lanthium chloride. Further dilutions for each mineral as well as calibration curves, wavelengths and flame parameters were optimized for a GBC 932 AA in accordance with the instruments manufacturer's recommendations (GBC Scientific Equipment, Inc., Arlington Heights, Ill.).

All data shown in the tables were normalized to $11.5^{\circ}$ Brix to match the FDA definition for $100 \%$ apple juice. Total acidity data were expressed as percent of malic acid equivalents per $100 \mathrm{~g}$ of juice. Carbohydrate data were expressed as $\mathrm{g} / 100 \mathrm{~mL}$, acid data as $\mathrm{mg} / 100$ $\mathrm{mL}$ and minerals as $\mathrm{mg} / 100 \mathrm{~mL}$. All juice dilutions, standards and reagents were prepared from $18 \mathrm{Mohm}$ water. Analysis of variance was determined by MSTAT-C (1989) using bioregulators and harvest date as main effects. On the basis of significant $F$ tests, bioregulator treatment means were separated by Tukey's test $(P \leq 0.05)$. Harvest-date data were separated by single-df analysis of variance comparisons.
Significant interactions between bioregulators and harvest dates were not found.

\section{Results and Discussion}

Trial 1 (2000). ETH applied at either concentration $2 \mathrm{WBFH}$ or at the higher concentration $1 \mathrm{WBFH}$ (300 ppm) increased the Brix value in expressed juice at harvest (Table 1). Juice sucrose content was significantly increased in all ETH treatment/time combinations. Neither a higher ETH concentration nor longer exposure time to ETH before harvest produced a greater increase in sucrose. In contrast, fructose concentration in apple juice was reduced by ETH except for the lower concentration at the shorter preharvest interval (150 ppm application $1 \mathrm{WBFH}$ ). Sorbitol concentration in juice was increased by both concentrations of ETH applied 2 WBFH but not by similar treatments

Table 1. ETH effects on Brix, total acidity, carbohydrate and acid concentrations in 'Scarletspur Delicious' apple juice (Trial 1).

\begin{tabular}{|c|c|c|c|c|c|c|c|c|c|}
\hline \multirow[b]{2}{*}{ Parameter } & \multirow[b]{2}{*}{ Brix $^{\circ}$} & \multicolumn{4}{|c|}{ Carbohydrates $(\mathrm{g} / 100 \mathrm{~mL})$} & \multirow{2}{*}{$\begin{array}{c}\text { Total } \\
\text { acidity }(\%)\end{array}$} & \multicolumn{3}{|c|}{ Acids (mg/100 mL) } \\
\hline & & Sucrose & Glucose & Fructose & Sorbitol & & Quinic & Malic & Citric \\
\hline \multicolumn{10}{|l|}{ Bioregulator } \\
\hline Control & $10.9 \mathrm{~b}^{\mathrm{z}}$ & $2.27 \mathrm{c}$ & $2.53 \mathrm{a}$ & $6.00 \mathrm{a}$ & $0.29 \mathrm{c}$ & $0.27 \mathrm{a}$ & $88.6 \mathrm{a}$ & $338.1 \mathrm{a}$ & $3.5 \mathrm{a}$ \\
\hline ETH@150 ppm (2WBFH) $)^{\mathrm{y}}$ & $11.8 \mathrm{a}$ & $2.59 \mathrm{ab}$ & $2.53 \mathrm{a}$ & $5.64 \mathrm{~cd}$ & $0.36 \mathrm{ab}$ & $0.23 \mathrm{~b}$ & $79.4 \mathrm{~b}$ & $306.0 \mathrm{ab}$ & $3.7 \mathrm{a}$ \\
\hline ETH@300 ppm (2WBFH) & $11.9 \mathrm{a}$ & $2.69 \mathrm{a}$ & $2.49 \mathrm{a}$ & $5.57 \mathrm{~d}$ & $0.39 \mathrm{a}$ & $0.23 \mathrm{~b}$ & $75.3 \mathrm{~b}$ & $303.6 \mathrm{~b}$ & $3.5 \mathrm{a}$ \\
\hline ETH@150 ppm $(1 \mathrm{WBFH})^{\mathrm{x}}$ & $11.4 \mathrm{ab}$ & $2.50 \mathrm{~b}$ & $2.55 \mathrm{a}$ & $5.85 \mathrm{ab}$ & $0.30 \mathrm{bc}$ & $0.24 \mathrm{ab}$ & $82.7 \mathrm{ab}$ & $319.9 \mathrm{ab}$ & $3.8 \mathrm{a}$ \\
\hline ETH@300 ppm (1WBFH) & $11.7 \mathrm{a}$ & $2.53 \mathrm{ab}$ & $2.58 \mathrm{a}$ & $5.80 \mathrm{bc}$ & $0.33 \mathrm{bc}$ & $0.23 \mathrm{~b}$ & $81.2 \mathrm{ab}$ & $298.8 \mathrm{~b}$ & $3.6 \mathrm{a}$ \\
\hline \multicolumn{10}{|l|}{ Harvest } \\
\hline $18 \mathrm{Sept}$ & $11.1 \mathrm{~b}$ & $2.47 \mathrm{~b}$ & $2.52 \mathrm{a}$ & $6.06 \mathrm{a}$ & $0.27 \mathrm{~b}$ & $0.26 \mathrm{a}$ & $91.1 \mathrm{a}$ & $334.6 \mathrm{a}$ & $3.8 \mathrm{a}$ \\
\hline 13 Oct & $12.0 \mathrm{a}$ & $2.56 \mathrm{a}$ & $2.55 \mathrm{a}$ & $5.48 \mathrm{~b}$ & $0.39 \mathrm{a}$ & $0.22 \mathrm{~b}$ & $71.8 \mathrm{~b}$ & $262.0 \mathrm{~b}$ & $3.5 \mathrm{~b}$ \\
\hline
\end{tabular}

${ }^{\mathrm{z}}$ Means in a column within bioregulators or harvest not followed by a common letter are significantly different $(P \leq 0.05)$.

'ETH applied 2 weeks before anticipated harvest.

${ }^{x}$ ETH applied 1 week before anticipated harvest.

Table 2. AVG and ETH effects on Brix, total acidity, carbohydrate and acid concentrations in 'Scarletspur Delicious' apple juice (Trial 2).

\begin{tabular}{|c|c|c|c|c|c|c|c|c|c|}
\hline \multirow[b]{2}{*}{ Parameter } & \multirow[b]{2}{*}{ Brix $^{\circ}$} & \multicolumn{4}{|c|}{ Carbohydrates $(\mathrm{g} / 100 \mathrm{~mL})$} & \multirow{2}{*}{$\begin{array}{c}\text { Total } \\
\text { acidity (\%) }\end{array}$} & \multicolumn{3}{|c|}{ Acids $(\mathrm{mg} / 100 \mathrm{~mL})$} \\
\hline & & Sucrose & Glucose & Fructose & Sorbitol & & Quinic & Malic & Citric \\
\hline Control & $10.8 \mathrm{bc}^{2}$ & $2.22 \mathrm{a}$ & $1.50 \mathrm{c}$ & $6.17 \mathrm{ab}$ & $0.26 \mathrm{a}$ & $0.31 \mathrm{ab}$ & $137.2 \mathrm{~b}$ & $427.2 \mathrm{a}$ & $4.91 \mathrm{a}$ \\
\hline AVG ${ }^{\mathrm{y}}+\mathrm{ETH} @ 150$ ppm $(2 \mathrm{WBFH})^{\mathrm{x}}$ & $11.3 \mathrm{ab}$ & $2.31 \mathrm{a}$ & $1.68 \mathrm{a}$ & $5.98 \mathrm{bc}$ & $0.30 \mathrm{a}$ & $0.30 \mathrm{ab}$ & $135.2 \mathrm{bc}$ & $383.6 \mathrm{~b}$ & $3.58 \mathrm{c}$ \\
\hline $\mathrm{AVG}^{\mathrm{y}}+\mathrm{ETH} @ 300$ ppm $(2 \mathrm{WBFH})^{\mathrm{x}}$ & $11.9 \mathrm{a}$ & $2.28 \mathrm{a}$ & $1.85 \mathrm{a}$ & $5.87 \mathrm{c}$ & $0.31 \mathrm{a}$ & $0.27 \mathrm{~b}$ & $120.2 \mathrm{c}$ & $366.4 \mathrm{~b}$ & $3.19 \mathrm{~d}$ \\
\hline $\mathrm{AVG}^{\mathrm{y}}+\mathrm{ETH} @ 150$ ppm $(1 \mathrm{WBFH})^{\mathrm{w}}$ & $11.3 \mathrm{ab}$ & $2.31 \mathrm{a}$ & $1.56 \mathrm{bc}$ & $6.02 \mathrm{bc}$ & $0.28 \mathrm{a}$ & $0.28 \mathrm{bc}$ & $126.5 \mathrm{c}$ & $381.4 \mathrm{~b}$ & $3.47 \mathrm{~cd}$ \\
\hline $\mathrm{AVG}^{\mathrm{y}}+\mathrm{ETH} @ 300$ ppm $(1 \mathrm{WBFH})^{\mathrm{w}}$ & $11.8 \mathrm{a}$ & $2.30 \mathrm{a}$ & $1.79 \mathrm{ab}$ & $5.84 \mathrm{c}$ & $0.31 \mathrm{a}$ & $0.25 \mathrm{c}$ & $123.1 \mathrm{c}$ & $369.1 \mathrm{~b}$ & $3.54 \mathrm{~cd}$ \\
\hline $8 \mathrm{Oct}$ & $11.9 \mathrm{a}$ & $2.42 \mathrm{a}$ & $1.75 \mathrm{a}$ & $5.80 \mathrm{~b}$ & $0.31 \mathrm{a}$ & $0.25 \mathrm{~b}$ & $98.3 \mathrm{~b}$ & $334.7 \mathrm{~b}$ & $3.27 \mathrm{~b}$ \\
\hline
\end{tabular}

${ }^{\mathrm{z}}$ Means in a column within bioregulators or harvest not followed by a common letter are significantly different $(P \leq 0.05)$.

${ }^{y} \mathrm{AVG}$ applied 4 weeks before anticipated harvest.

${ }^{x}$ ETH applied 2 weeks before anticipated harvest

${ }^{\mathrm{w}} \mathrm{ETH}$ applied 1 week before anticipated harvest.

Table 3. AVG and ETH effects on Brix, total acidity, carbohydrate and acid concentrations in 'Scarletspur Delicious' apple juice (Trial 3).

\begin{tabular}{|c|c|c|c|c|c|c|c|c|c|}
\hline \multirow[b]{2}{*}{ Parameter } & \multirow[b]{2}{*}{ Brix $^{\circ}$} & \multicolumn{4}{|c|}{ Carbohydrates $(\mathrm{g} / 100 \mathrm{~mL})$} & \multirow{2}{*}{$\begin{array}{c}\text { Total } \\
\text { acidity }(\%)\end{array}$} & \multicolumn{3}{|c|}{ Acids $(\mathrm{mg} / 100 \mathrm{~mL})$} \\
\hline & & Sucrose & Glucose & Fructose & $\overline{\text { Sorbitol }}$ & & $\overline{\text { Quinic }}$ & Malic & Citric \\
\hline Control & $12.0 \mathrm{a}^{\mathrm{z}}$ & $2.27 \mathrm{a}$ & $1.97 \mathrm{a}$ & $5.87 \mathrm{ab}$ & $0.37 \mathrm{a}$ & $0.24 \mathrm{ab}$ & $97.6 \mathrm{a}$ & $350.7 \mathrm{ab}$ & $4.58 \mathrm{a}$ \\
\hline ETH@ 95 ppm (2 and 1 WBFH $)^{x}$ & $12.2 \mathrm{a}$ & $2.10 \mathrm{ab}$ & $2.00 \mathrm{a}$ & $5.73 \mathrm{~b}$ & $0.38 \mathrm{a}$ & $0.24 \mathrm{ab}$ & $79.0 \mathrm{~b}$ & $360.3 \mathrm{a}$ & $4.16 \mathrm{a}$ \\
\hline ETH @ 150 ppm (2 WBFH) $)^{\mathrm{w}}$ & $12.4 \mathrm{a}$ & $2.06 \mathrm{ab}$ & $2.04 \mathrm{a}$ & $5.80 \mathrm{~b}$ & $0.41 \mathrm{a}$ & $0.22 \mathrm{~b}$ & $93.6 \mathrm{a}$ & $325.6 \mathrm{~b}$ & $3.98 \mathrm{a}$ \\
\hline $\mathrm{AVG}^{\mathrm{y}}+\mathrm{ETH} @ 75$ ppm $(2 \text { and } 1 \mathrm{WBFH})^{\mathrm{x}}$ & $12.2 \mathrm{a}$ & $2.17 \mathrm{a}$ & $2.12 \mathrm{a}$ & $5.73 \mathrm{~b}$ & $0.36 \mathrm{a}$ & $0.23 \mathrm{~b}$ & $94.4 \mathrm{a}$ & $347.7 \mathrm{ab}$ & $4.36 \mathrm{a}$ \\
\hline $\mathrm{AVG}^{\mathrm{y}}+\mathrm{ETH} @ 150 \mathrm{ppm}(2 \mathrm{WBFH})^{\mathrm{w}}$ & $12.1 \mathrm{a}$ & $2.20 \mathrm{a}$ & $2.04 \mathrm{a}$ & $5.75 \mathrm{~b}$ & $0.37 \mathrm{a}$ & $0.24 \mathrm{ab}$ & $90.5 \mathrm{ab}$ & $343.4 \mathrm{ab}$ & $4.37 \mathrm{a}$ \\
\hline 21 Oct & $12.8 \mathrm{a}$ & $2.30 \mathrm{a}$ & $1.95 \mathrm{~b}$ & $5.68 \mathrm{~b}$ & $0.45 \mathrm{a}$ & $0.21 \mathrm{~b}$ & $75.3 \mathrm{~b}$ & $313.7 \mathrm{~b}$ & $3.55 \mathrm{~b}$ \\
\hline
\end{tabular}

${ }^{2}$ Means in a column within bioregulators or harvest not followed by a common letter are significantly different $(P \leq 0.05)$.

yAVG applied 4 weeks before anticipated harvest.

${ }^{x}$ ETH applied 2 weeks and again 1 week before anticipated harvest.

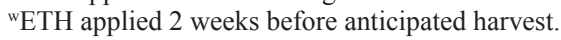


$1 \mathrm{WBFH}$. There was no ETH effect on glucose concentrations. Although ETH increased both Brix and sucrose in apple juice, the reduction of fructose, which is sweeter than sucrose (Banasiak, 2003), might alter the perception of sweetness. A 4-week delay in harvest resulted in increased Brix, sucrose and sorbitol concentrations and reduced fructose concentration of apple juice. Glucose was not influenced by a delay in harvest. Harvest-date-related changes in juice composition have not been previously noted (Drake and Eisele, 1999).

Total acidity in juice was significantly reduced by all treatments except $150 \mathrm{ppm}$ ETH applied 1WBFH (Table 1). Citric acid concentration was unrelated to either amount of ETH or time of application. Quinic acid concentration was reduced by both ETH applications at $2 \mathrm{WBFH}$, while malic acid concentration was reduced only by treatment with $300 \mathrm{ppm}$
ETH, regardless of time before harvest. Delay of harvest resulted in apple juice with reduced total acidity and individual acid concentrations. The reduction in total acid concentration with delayed harvest has been previously reported (Drake etal., 2002b). The changes in individual acids with delayed harvest reported here have not been well documented.

Trial 2 (2001). AVG alone reduced sucrose concentration of apple juice at harvest but had no effect on glucose, fructose, sorbitol or total Brix (Table 2). ETH at 300 ppm applied either two or three weeks after AVG increased juice Brix and glucose levels above the levels in untreated fruit and decreased fructose concentration. Juice glucose was also increased by ETH at 150 ppm if applied 2 weeks after AVG (2 WBFH) but not if applied 3 weeks after AVG (i.e., $1 \mathrm{WBFH}$ ). Delaying harvest by 4 weeks resulted in increased juice Brix, sucrose, glucose and sorbitol concentrations and decreased fructose concentration, which is in agreement with observations the first year of the study.

AVG alone resulted in juice with increased quinic acid and reduced citric acid concentrations but had no influence on malic acid level or total acidity compared to control apple juice (Table 2). ETH treatment of previously AVGtreated apples resulted in reduced concentrations of quinic, malic and citric acids, with the exception of ETH 150 ppm at 2 WBH. Despite these reductions in individual acid levels, only ETH at $300 \mathrm{ppm}$ applied $1 \mathrm{WBFH}$ reduced total acidity. Delaying harvest by 4 weeks resulted in reductions in total acidity as well as concentrations of all three of the individual acids measured.

Trial 3 (2002). At harvest, AVG-treated fruit showed reduced juice Brix, sucrose and

Table 4. ETH effects on selected mineral concentrations in apple juice from 'Scarletspur Delicious' apples (Trial 1).

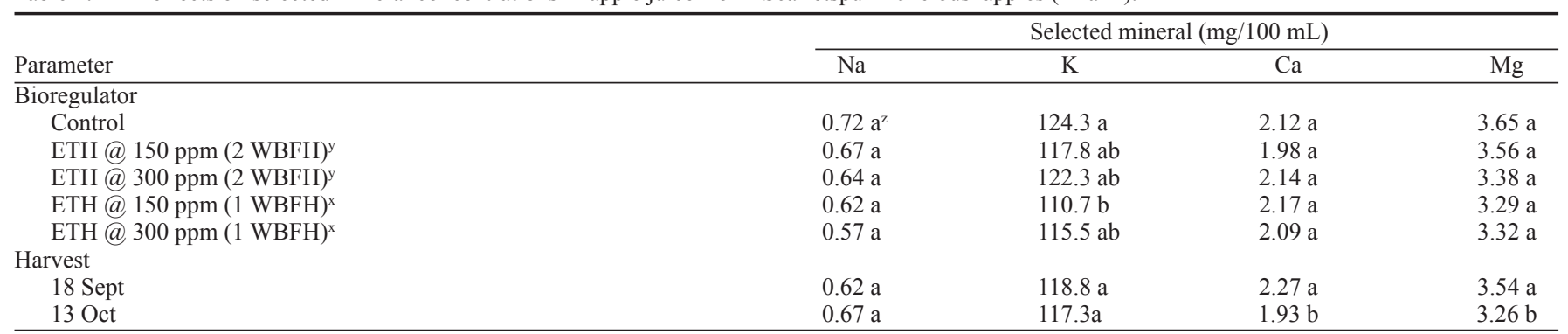

${ }^{2}$ Means in a column within bioregulators or harvest not followed by a common letter are significantly different $(P \leq 0.05)$.

${ }^{\mathrm{y} E T H}$ applied 2 weeks before anticipated harvest

${ }^{x}$ ETH applied 1 week before anticipated harvest.

Table 5. AVG and ETH effects on selected mineral concentrations in apple juice from 'Scarletspur Delicious' apples (Trial 2).

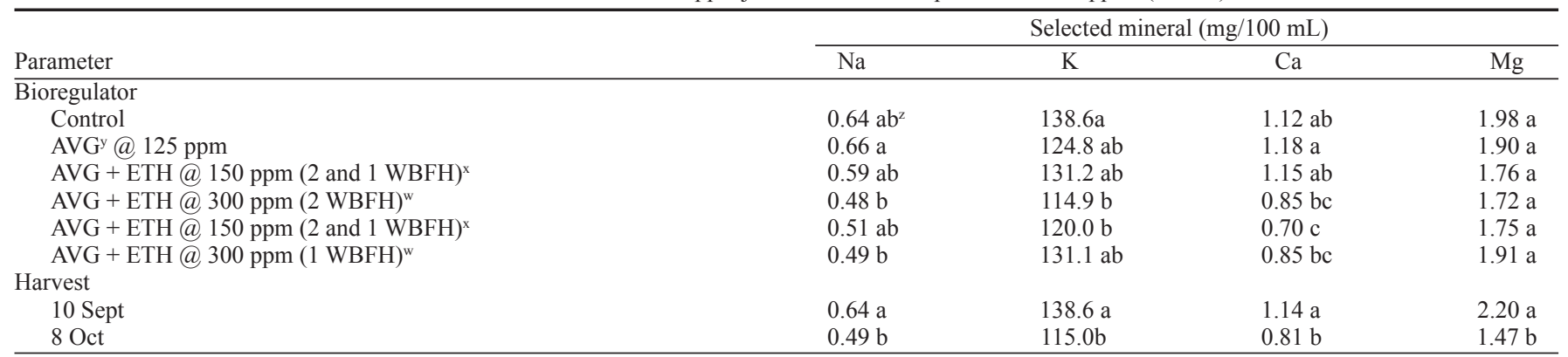

${ }^{2}$ Means in a column within bioregulators or harvest not followed by a common letter are significantly different $(P \leq 0.05)$.

yAVG applied 4 weeks before anticipated harvest.

${ }^{x}$ ETH applied 2 weeks before anticipated harvest

${ }^{\mathrm{w}}$ ETH applied 1 week before anticipated harvest.

Table 6. AVG and ETH effects on selected mineral concentrations in apple juice from 'Scarletspur Delicious' apples (Trial 3).

\begin{tabular}{|c|c|c|c|c|}
\hline \multirow[b]{2}{*}{ Parameter } & \multicolumn{4}{|c|}{ Selected mineral $(\mathrm{mg} / 100 \mathrm{~mL})$} \\
\hline & $\mathrm{Na}$ & $\mathrm{K}$ & $\mathrm{Ca}$ & $\mathrm{Mg}$ \\
\hline \multicolumn{5}{|l|}{ Bioregulator } \\
\hline Control & $0.29 \mathrm{~b}^{\mathrm{z}}$ & $100.8 \mathrm{~b}$ & $1.19 \mathrm{~b}$ & $1.45 \mathrm{~b}$ \\
\hline ETH@ $@ 75$ ppm $(2 \text { and } 1 \text { WBFH })^{x}$ & $0.45 \mathrm{a}$ & $105.2 \mathrm{ab}$ & $1.30 \mathrm{ab}$ & $1.64 \mathrm{ab}$ \\
\hline ETH@150 ppm (2 WBFH) & $0.21 \mathrm{~b}$ & $111.3 \mathrm{ab}$ & $1.44 \mathrm{a}$ & $1.66 \mathrm{ab}$ \\
\hline $\mathrm{AVG}+\mathrm{ETH} @ 75 \mathrm{ppm}(2 \text { and } 1 \mathrm{WBFH})^{\mathrm{x}}$ & $0.25 \mathrm{~b}$ & $108.7 \mathrm{ab}$ & $1.27 \mathrm{ab}$ & $1.56 \mathrm{~b}$ \\
\hline AVG + ETH @ 150 ppm (2 WBFH $)^{\mathrm{w}}$ & $0.21 \mathrm{~b}$ & $113.1 \mathrm{a}$ & $1.37 \mathrm{ab}$ & $1.78 \mathrm{a}$ \\
\hline 21 Oct & $0.28 \mathrm{~b}$ & $100.1 \mathrm{~b}$ & $1.15 \mathrm{~b}$ & $1.38 \mathrm{~b}$ \\
\hline
\end{tabular}

${ }^{2}$ Means in a column within bioregulators or harvest not followed by a common letter are significantly different $(P \leq 0.05)$.

${ }^{y} \mathrm{AVG}$ applied 4 weeks before anticipated harvest.

${ }^{\times}$ETH applied 2 weeks and again 1 week before anticipated harvest.

${ }^{\mathrm{w}} \mathrm{ETH}$ applied weeks before anticipated harvest. 
sorbitol concentrations compared to control juice, but glucose and fructose levels were unchanged (Table 3). ETH either alone or applied after AVG had no effect on Brix or any of the sugars measured compared to control juice samples. However, either ETH treatment following application of AVG returned total juice Brix and sucrose concentrations to control levels. As in the previous two trials, delaying harvest 4 weeks increased Brix, sucrose and sorbitol concentrations and reduced the amount of fructose present in apple juice. In this trial, juice glucose content was reduced at the later harvest date. This observation is in contrast to the previous two trials, in which juice glucose content was either not influenced by harvest date or increased at the later harvest date.

AVG alone had no influence on juice total acidity and the individual acids (quinic, malic and citric) compared to juice from control apples (Table 3). AVG effects on acid levels parallel the results reported in Table 2 except for citric acid, which was reduced by AVG. Changes in juice total acidity and the levels of quinic, malic and citric acids were not as clear when ETH was applied at 75 and 150 ppm (Table 3) than when applied at 150 and $300 \mathrm{ppm}$ (Table 2). The results from this trial suggest that ETH must be applied at concentrations at or above $150 \mathrm{ppm}$ to have a significant effect on acid levels. As with earlier results, delay of harvest reduced total acidity and the amounts of the three individual acids evaluated in apple juice.

Trial 1 (2000). Application of ETH had little or no influence on the mineral ( $\mathrm{Na}, \mathrm{K}, \mathrm{Ca}$, $\mathrm{Mg}$ ) concentrations of apple juice compared to juice from control apples (Table 4). There was a decrease in juice $\mathrm{K}$ concentration when ETH was applied at $150 \mathrm{ppm} 1 \mathrm{WBFH}$, but the reduction was very slight and would not be considered of interest. Delayed harvest reduced the $\mathrm{Ca}$ and $\mathrm{Mg}$ concentrations of juice but had no influence on the concentrations of $\mathrm{Na}$ or K. It is doubtful that any of the mineral changes due to ETH application or delay in harvest would have a significant impact on apple juice quality.

Trial 2 (2001). Application of AVG alone had no influence on the juice concentrations of $\mathrm{Na}, \mathrm{K}, \mathrm{Ca}$, or $\mathrm{Mg}$ in treated apples (Table 5). Application of ETH after AVG had no effect on the $\mathrm{Na}$ or $\mathrm{Mg}$ concentrations in juice. A few of the combination treatments of AVG and ETH produced small but statistically significant reductions in either or both $\mathrm{K}$ and $\mathrm{Ca}$ concentrations of apple juice. The amount of Ca present in apples has been directly related to multiple apple disorders (Fallahi et al, 1988; Fallahi and Simons, 1996). Delay of harvest resulted in a reduction in juice concentration of all minerals measured.

Trial 3 (2002). AVG applied alone the final year of the study increased the Na concentration of apple juice, but had no additional influence on other selected minerals (Table 6). The influence of AVG on Na concentration in 2002 may be related to the fact that juice $\mathrm{Na}$ concentration was much lower in 2002 as compared to the previous year (2001, Table 5 ). The juice concentrations of $\mathrm{K}, \mathrm{Ca}$, and
$\mathrm{Mg}$ were similar among years. There were few significant differences in juice mineral concentrations associated with treatments, and it is unlikely that any of these differences would have materially affected either storability or perceived fruit quality. Delay of harvest decreased all mineral concentrations.

\section{Conclusions}

Preharvest ETH treatment of 'Scarletspur Delicious' apples enhanced the Brix and sucrose concentrations and reduced fructose concentration in juice. Effects on glucose and sorbitol levels were not consistent among years in this study. Exposure to either higher ETH concentration or to a longer preharvest ETHto-harvest interval appeared to have a stronger influence than application closer to first harvest and/or at lower concentrations. Glucose content of apple juice was not consistently affected, regardless of the bioregulator used or the time of harvest. ETH reduced juice total acidity and, when applied early, and particularly at higher concentrations, reduced individual juice acid (quinic and malic) concentrations. Use of AVG reduced both juice Brix value and sucrose concentration in juice but had no influence on either juice total acidity or individual acid concentrations. Applying ETH following AVG tended to reverse the negative effects of AVG on solids and individual sugar levels, while pre-treatment with AVG appeared to partially mitigate $\mathrm{ETH}$-induced reductions in acidity in juice. Increased juice Brix values coupled with reduced total acidity would improve the overall solids/acid ratio, thereby possibly having a strong positive influence on the sensory quality of 'Delicious' apples. Use of ETH, AVG, or a combination of AVG and ETH had little or no consistent influence on the juice mineral content of 'Delicious' apples and thus would not be expected to affect mineral-nutrient-related fruit quality characteristics.

\section{Literature Cited}

Andrews P.K. 2001. Gala splitting. Proc. Wash. Tree Fruit Postharvest Conf., 13-14 Mar., Wenatchee.

AOAC. 1990. Official methods of analysis. 15th ed. AOAC, Arlington, Va.

Banasiak, K. 2003. Formulating with fruit. Food Product Design 13:37-56.

Bangerth, F. 1978. The effects of substituted amino acid on ethylene biosynthesis, respiration, ripening and preharvest drop of apple fruit. J. Amer. Soc. Hort. Sci. 103:401-404.

Beaudry, R.and S. Jayanty. 2003. Improving McIntosh storability: Amarriage of ReTain and SmartFresh. The Fruit Grower News 42:38-39.

Byers, R.E. 1997. Effects of aminoethoxyvinylglycine (AVG) on preharvest drop, maturity, and cracking of several apple cultivars. J. Tree Fruit Prod. 2:77-97.

Drake, S.R. and T.A. Eisele. 1999. Carbohydrate and acid content of Gala apples and Bartlett pears from regular and controlled atmosphere storage. J. Agr. Food Chem. 47:3181-3184.

Drake, M.A., S.R. Drake, D.C. Elfving, and T.A. Eisele. 2002a. Influence of bioregulators on apple fruit quality. Proc. Inst. Food Technol. Annu. Mtg., 15-19 June, Anaheim, Calif.

Drake, S.R., D.C. Elfving, and T.A. Eisele. 2002b.
Harvest maturity and storage affect quality of 'Cripps Pink' (Pink Lady) apples. HortTechnology 12:388-391.

Drake, S.R., D.C. Elfving, T.A. Eisele, M.A. Drake, S.L. Drake, and D.B. Visser. 2003. Effects of ETH and aminoethoxyvinylglycine on the carbohydrate and acids contents of 'Scarletspur Delicious' apples (Malus domestica Borkh.). Proc. Inst. Food Technol. Annu.Mtg., 12-16 July, Chicago, Ill.

Eisele, T.A and S.R. Drake. 2003. The partial compositional characteristics of apple juice from one hundred seventy-five apple varieties. J. Food Comp. Anal. 18:213-221.

Elfving, D.C. and R.A. Cline. 1990. Effects of annually applied growth control techniques on growth and productivity of vigorous 'Northern Spy'/MM.106 apple trees. J. Amer. Soc. Hort. Sci. 115:212-218.

Elfving, D.C., G.A. Lang, and D.B. Visser. 2003. Prohexadione-Ca and ethephon reduce shoot growth and increase flowering in young, vigorous sweet cherry trees. HortScience 38:293-298.

Elkins, E.R., A. Matthys, R. Lyon, and C.J. Huany. 1996. Characterization of commercially produced apple juice concentrate. J. Food Comp. Anal. 9:43-56.

Fallahi, E., T.L. Righetti, and J.T. Raese. 1988. Ranking tissue mineral analyses to identify mineral limitation on quality in fruit. J. Amer. Soc. Hort. Sci. 113:382-389.

Fallahi, E. and B.R. Simons. 1996. Interrelations among leaf and fruit mineral nutrients and fruit quality in 'Delicious' apples. J. Tree Fruit Prod. $1: 15-25$.

Greene, D.W., J. Krupa, and J. Clements. 2000. Effects of simulated rain following ReTain application on preharvest drop and fruit quality of McIntosh apples. Fruit Notes 60:57-60.

Greene, D.W. 2002. Preharvest drop control and maturity of 'Delicious' apples as affected by aminoethoxyvinylglycine (AVG). J. Tree Fruit Prod. 3:1-10.

Halder-Doll H. and F. Bangerth. 1987. Inhibition of autocatalytic $\mathrm{C}_{2} \mathrm{H}_{4}$ biosynthesis of AVG applications and consequences on the physiological behavior and quality of apples fruit in cool storage. Scientia Hort. 33:87-96.

Layne, D.R., J.Zhengwang, and J.W. Rushing. 2002. The influence of reflective film and ReTain on red skin coloration and maturity of 'Gala' apples. HortTechnology 12:640-645.

Larrigaudiere, C., E. Pinto, and M. Vendrell. 1996. Differential effects of ethephon and seniphos on color development of 'Starking Delicious' apple. J. Amer. Soc. Hort. Sci. 121:746-750.

Lee, J.S. and R.E. Wrolstad. 1988. Apple juice composition: Sugar, nonvolatile acid and phenolic profiles. J. Assn. Off. Anal. Chem. 71:789-794.

Stover, E., M.J. Fargione, C.B. Watkins, and K.A. Iungerman. 2003. Harvest management of 'Marshall McIntosh' apples: Effects of AVG, NAA, ethephon, and summer pruning on preharvest drop and fruit quality. HortScience 38:1093-1099.

Wang,Z. and D.R. Dilley. 2001. Aminoethoxyvinylglycine, combined with ethephon, can enhance red color development without over-ripening apples. HortScience 36:328-331.

Watkins, C.B. and D.A. Rosenberger. 1999. Items of interest for storage operators in New York and beyond. Cornell Fruit Handling Storage Nwslt.

Williams, M.W. 1980. Retention of fruit firmness and increase in vegetative growth and fruit set of apples with aminoethoxyvinylglycine. HortScience 15:76-77. 